Article

\title{
The League of Matteo Salvini: Fostering and Exporting a Modern Mass-Party Grounded on "Phygital” Activism
}

\author{
Mattia Zulianello \\ Department of Political and Social Sciences, University of Trieste, Italy; E-Mail: mattia.zulianello@dispes.units.it
}

Submitted: 29 May 2021 | Accepted: 31 August 2021 | Published: 24 November 2021

\begin{abstract}
The Lega Nord (LN) has undergone a profound process of transformation since 2013, by replacing its historical regionalist populism with a new state-wide populist radical right outlook. However, very little is known about how such transformation impacted its organizational model, particularly the mass-party features that characterized it under its founding leader, Umberto Bossi. This article explores the organizational evolution of the party under Matteo Salvini by means of a qualitative in-depth analysis of 41 semi-structured interviews with representatives of the LN from four regions (Calabria, Emilia-Romagna, Lombardy, and Veneto) and primary documents. It underlines that the LN was turned into a disempowered and politically inactive "bad company," charged with the task of paying the debts of the old party, while its structure, resources, and personnel were poured into a new state-wide organization called Lega per Salvini Premier (LSP). The LSP has not simply maintained the key features of the mass-party in the LN's historical strongholds, but also pioneered a modern form of this organizational model grounded on the continuous interaction between digital and physical activism, i.e., "phygital activism," which boosts the party's ability to reach out to the electorate by delivering the image that the League is constantly on the ground. The LSP has sought to export this modern interpretation of the mass-party in the South; however, in that area its organizational development remains at an embryonic stage, and the party's nationalization strategy has so far produced a "quasi-colonial" structure dominated by, and dependent on, the Northern elite.
\end{abstract}

\section{Keywords}

centralization; Lega Nord; Matteo Salvini; mass-party; party nationalization; party organization; phygital activism; populist radical right

Issue

This article is part of the issue "Right-Wing Populist Party Organisation Across Europe: The Survival of the Mass-Party?" edited by Daniele Albertazzi (University of Surrey, UK) and Stijn van Kessel (Queen Mary University of London, UK).

(C) 2021 by the author; licensee Cogitatio (Lisbon, Portugal). This article is licensed under a Creative Commons Attribution 4.0 International License (CC BY).

\section{Introduction}

For much of its existence, the Lega Nord (LN) was led by a Lombard elite dominated by its founding leader, Umberto Bossi, who concentrated his efforts on building a mass-party inspired by the organizational principles and practices of Leninist parties. While the existing literature has provided excellent analyses of the mass-party features of the "old" LN (e.g., Albertazzi, 2016; Albertazzi \& McDonnell, 2015; McDonnell \& Vampa, 2016), very little is known about how the disempowerment of the old LN in favour of a new, state-wide, organization called
Lega per Salvini Premier (LSP) impacted on its longstanding organizational model.

This article fills this gap by relying on the qualitative in-depth analysis of 41 semi-structured interviews with representatives of the LSP in Calabria, Emilia-Romagna, Lombardy, and Veneto, along with primary documents. In line with the analytical framework outlined in the introduction to this thematic issue on right-wing populist parties (Albertazzi \& van Kessel, 2021), this article explores the organizational structure of the new LSP, shedding light on how it attracts new members and activists, the role of the internet and social media in party organization 
and activism, the reasons to grow an active base of activists, and the degree of centralization of power and internal democracy.

This article is structured as follows: After a section presenting the research design and methods adopted, an outline of the historical evolution of the LN follows, explaining how the latter was transformed into a disempowered "bad company" in favour of the new LSP. Then, it explains how LSP has sought to foster and modernize the mass-party organizational model inherited from the old LN in the historical strongholds in the North, while seeking to export its key features to the whole country. The article subsequently discusses the hypercentralized nature of the LSP and the virtual lack of internal democracy-features that are interlinked with the long-standing imperative of democratic centralism that characterized Bossi's LN since its origins.

This article shows that the LSP has successfully developed a modern conception of the mass-party grounded on the key principle of "phygital" activism, which combines physical activism on the ground and digital activism, suggesting that a traditional organizational model can be updated by taking advantage of new technologies. Phygital activism is well-oiled and fostered in Northern regions, where it enables the LSP to perform the traditional functions of the mass-party model in a faster, more efficient, and immediate way.

This modern conception of the mass-party model is consolidated in the North and has been exported to the South. However, the strategy of organizational nationalization of the LSP is still in its infancy, and territorial penetration in the South is being pursued in a "quasi-colonial" way by Salvini and his most loyal collaborators, raising doubts about its future sustainability.

\section{Research Design and Methods}

By adopting the analytical framework outlined in the introduction to this thematic issue, this article tackles two major points. First, it assesses whether the new LSP has maintained key features of the mass-party organizational model, which were evident during Bossi's era, despite the profound change of its ideology and geographic scope under the leadership of Matteo Salvini. Second, the article explores the strategy of organizational nationalization of a (formerly) regionalist party which, for much of its history, had found its raison d'être in a delimited geographic area (i.e., Northern Italy). Hence, the LSP as a case-study can substantially enhance our understanding of how parties implement "strategic decisions of adopting organizational changes in order to pursue their goals" (Borz \& Janda, 2020, p. 3) as well as that of party nationalization strategies (e.g., Borz \& De Miguel, 2019).

In this respect, it is worth recalling that Stockemer et al. (2018) argued that the study of the demand-side of populist radical right politics can be greatly improved through in-depth analyses, providing room for voices from within the party. This article maintains that focusing on the attitudes, views, and perspectives from within the party is even more pressing when it comes to the study of party organization, an essential feature of the supplyside of populist politics (see Heinisch \& Mazzoleni, 2016).

Hence, methodologically speaking, this article focuses on the detailed analysis of party statutes (LN, 2015, 2021; LSP, 2018) and regulations (LSP, 2021) and, in particular, on the qualitative in-depth analysis of 41 semi-structured interviews with representatives and former representatives of the LN and/or LSP in Calabria, Emilia-Romagna, Lombardy, and Veneto, conducted between November 2019 and June 2021. These regions were chosen to maximize variation in terms of party history, strength, and organizational development: the historical power centre of the LN/LSP (Lombardy), its current electoral stronghold (Veneto), an area in which the left has historically been dominant (Emilia-Romagna), and a Southern region where the party has attempted to export its organizational model (Calabria).

Interviewees were purposefully sampled: Snowball chains developed with those who agreed to be interviewed as well as with the help of the party, and participants were sought until theoretical saturation was reached (Kvale, 1996). All interviewees matched the criteria for purposive sampling as they are in a privileged position to shed light on the research questions mentioned above. All the interviewees occupy or occupied different roles within the LN/LSP at the various territorial levels of the party organization and/or or represent(ed) the LN/LSP in local, regional, or national institutions (for details see the Supplementary Material).

\section{From Lega Nord to the Division of Labour Between Two Leagues: The "Good" and the "Bad" Company}

The LN finds its roots in the mobilization of regionalist parties in Northern Italy since the late 1970s, which eventually merged in 1991 under the undisputed leadership of Bossi. Since then, LN has enjoyed uninterrupted parliamentary presence, making it the oldest parliamentary actor in the country. Even though its electoral performance has fluctuated over time (Figures 1 and 2), the impact of LN on Italian politics has been remarkable, as shown by its key role in coalition dynamics (Zulianello, 2019) and by its repeated participation in national governments (Albertazzi \& McDonnell, 2015).

LN played a critical role in the collapse of the party system that dominated Italian politics in the post-war period by bringing to the fore the so-called "Northern question." The LN successfully activated a dormant centre-periphery cleavage counterpoising the interest and values of the "hard-working" Northerners against those of the "vexatious" central state and the "lazy" Southerners: Thanks to such features, the ideational profile of the party was constituted, for much of its history, by a populist form of regionalism (Newth, 2019; also cf. Albertazzi \& McDonnell, 2015). 


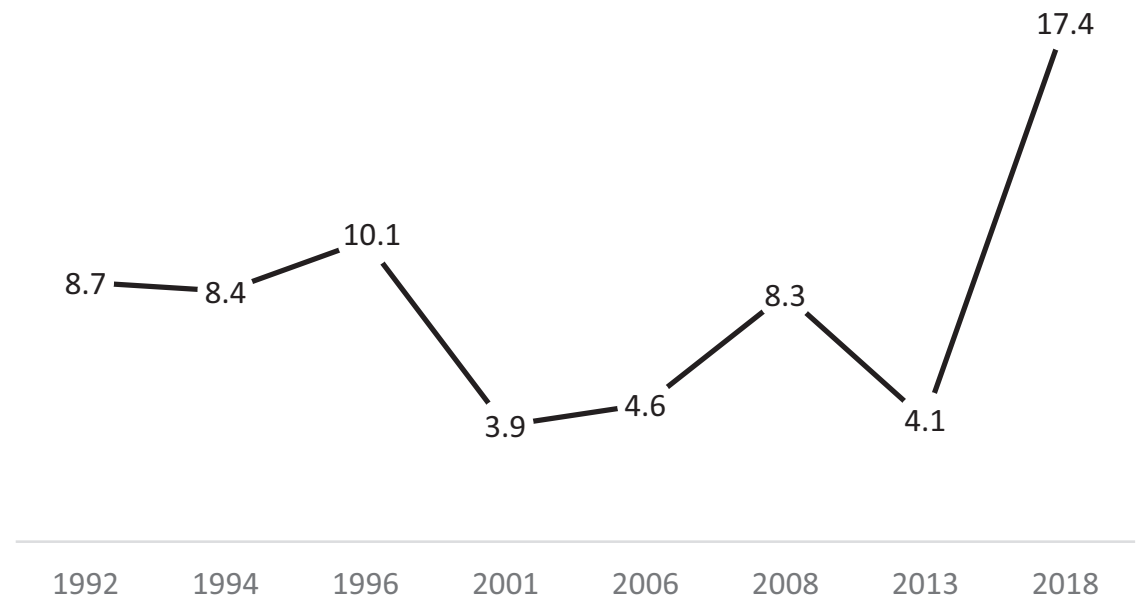

Figure 1. Vote share (in \%) in general elections (1992-2018, Chamber of Deputies). Source: Electoral Archive of the Italian Interior Ministry (2021).

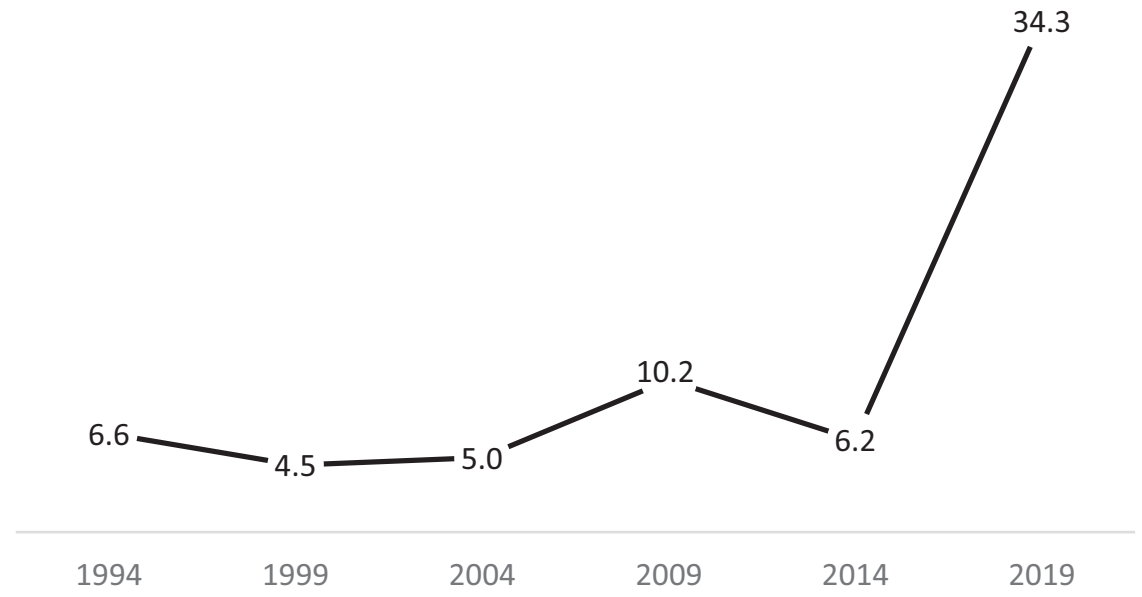

Figure 2. Vote share (in \%) in European elections (1994-2019). Source: Electoral Archive of the Italian Interior Ministry (2021).

Bossi was the uncontested leader of LN until 2012, when a scandal regarding the misappropriation of party funds led to his resignation. Following the short-lived leadership of Roberto Maroni, Matteo Salvini became the new Federal Secretary in 2013 and his election represented a key discontinuity in comparison with the past, since he did not belong to the founding group of the party. As Albertazzi et al. (2018, p. 662) underline, under Salvini "the regionalist cause was dropped... thus transforming in a most profound way one of the key components of the LN's ideology." Even though there are good reasons to identify populism and nativism as elements of continuity between the "old" and the "new" LN (Newth, 2019), the ideological trajectory undertaken by Salvini has made the party a fully-fledged populist radical right actor (Albertazzi et al., 2018; cf. Mudde, 2007, pp. 56-57). Before the 2018 general elections, the adjective "Northern" was even dropped from the electoral symbol of the party: On that occasion, LN made considerable inroads across the peninsula, including in the South (Albertazzi \& Zulianello, 2021), establishing itself as the leading force within the centre-right, with $17.4 \%$ of the votes and outpolling Forza Italia for the first time (14.0\%). Subsequently, it even became the most voted-for party in the country (34.3\% in the 2019 EU elections).

The abandonment of regionalist populism has been accompanied by the effort to export an organizational model tailored to a territorially defined area (the so-called Padania) to the whole Italian territory. The first steps in developing a state-wide organization were undertaken shortly after Salvini's election as party secretary of the LN, as in 2014 he launched a sister party called Noi con Salvini (NcS; literally "Us with Salvini") to contest sub-national elections in Southern Italy.

Meanwhile, the LN was facing increasing pressures from Italian authorities, who were investigating the scandal related to the misappropriation of party funds for private purposes that had led to Bossi's resignation in 2012. The amount of the fraud was estimated in EUR 49 million by judicial authorities; to prevent the risk of bankruptcy, Roberto Calderoli exited the parliamentary group of the $\mathrm{LN}$ in the senate in 2017 and deposited the statute of 
the new political actor LSP, which was published in the Official Gazette of the Italian Republic. This move, orchestrated by the Federal Council of the LN together with Calderoli, enabled the new LSP to be entitled to receive indirect public funding as well as private contributions, hence providing a "plan B" in case of an eventual freezing and confiscation of $L N$ funds by judicial authorities.

The establishment of the LSP resulted in a unique organizational parallelism: In the North, its structures, resources, and personnel de facto coincided with those of the old LN; in the South, the sister party NcS de facto dissolved into the new LSP. Nevertheless, such a parallelism had left unsolved the issue of protecting the LSP from the burden of the EUR 49 million debt-which the party had told prosecutors they would pay back in seven decades, in yearly instalments of EUR 600,000 a year-as well as formally transferring the members and structures of the LN into the new political actor. These issues were tackled in an extraordinary Federal Congress of the LN (held 21 December 2019), which unanimously approved a number of major changes to the federal statute, including the possibility of dual membership (i.e., in both LN and LSP). Such changes established a division of labour between two distinct entities: on the one hand, a "good company," the new LSP that is the only political and electoral actor left; on the other, a "bad company," the LN, which was "frozen" and continued to exist only to repay the already mentioned debt, mostly through "the voluntary contributions of its parliamentarians" (interview 4).

The final steps in the restructuring of the old LN occurred in early 2020. Salvini "froze" all the federal bodies of the disempowered LN, while appointing one of his most loyal collaborators (Igor lezzi) as its federal commissioner to prevent any potential resurgence of the "old" guard. Subsequently, through a series of notarial acts, the regional branches of the old $L N$ were re-founded as regional branches of the new League, led by commissioners directly appointed by Salvini and loyal to him.

\section{A Modern Mass-Party in the North, a Wannabe Mass-Party in the South}

The overall organizational logic of the LSP remains shaped by Bossi's very specific interpretation of the mass-party model: that of "a party with a Marxist mould" (interview 31). While inviting the reader to the abundant and rich literature on Bossi's LN for details (e.g., Albertazzi, 2016; Albertazzi \& McDonnell, 2015; Cento Bull \& Gilbert, 2001; McDonnell \& Vampa, 2016), for the present purposes it suffices to highlight that Bossi focused his efforts on developing an organization characterized by the essential features of mass-parties, that is, one characterised by a grassroots activist base, widespread territorial presence, and wide-ranging activities for party members, the latter encapsulated into a political community shaped by ideology. Bossi's LN was characterized by the paramount importance of physical and territorial activism, rigid screening mechanisms for activists' recruitment, and the formation of representatives through cadre schools, as well as by the development of a centralized party machine built upon the organizational imperative of democratic centralism.

In the North, the LSP inherited the organizational legacy of the $\mathrm{LN}$ and still carries out the traditional functions and activities characterizing the mass-party model by reinterpreting it in a modern way. In the South, the LSP is better understood as a "wannabe" mass-party at an embryonic stage of development, as it is trying to replicate the organizational features and practices it has consolidated in the North, but not without difficulties.

\subsection{Degree of Organization}

The LSP is characterized by a considerable "degree of organization," to use Janda's (1980) terminology, for two key reasons. First, the structures, resources and (the vast majority of) members of the old LN were poured into the new state-wide organization. Second, as the statute of the LSP (2018) is very similar to the LN's statute before its transformation into a bad company (LN, 2015), it is evident that the party has attempted to export its organizational model across the whole peninsula.

A comparison between the organizational chart of the LN (Figure 3) and that of the new LSP (Figure 4) highlights the disempowerment of the former in favour of the latter. In fact, crucial bodies and territorial levels of the party organization that are essential for conducting political activities do exist only in the new League (indicated in bold in Figure 4). Instead, the LN was "frozen," meaning that "there will be no secretaries, there will be no branches. It will be de-structured" (interview 4).

Differently from the LN, the new LSP maintains a high degree of organization and structural articulation, as well as vertical linkages (Figure 4), all of them key features of mass-parties (Panebianco, 1988). At the federal level, the key bodies of the LSP are the Federal Secretary, the Federal Council, the Federal Congress, and the Organizational and Territorial Federal Officer. The Federal Secretary coordinates and superintends all of the LSP's bodies and is granted extensive powers that virtually shape every aspect of party life. The Federal Congress convenes every three years: It is formally granted the power to elect the Federal Secretary, and its functions include setting the political and programmatic line and approving changes to the federal statute. The Federal Council is chaired and summoned by the Federal Secretary and includes, inter alia, the secretaries and representatives of the LSP's regional branches. It convenes every three months, and among its extensive prerogatives is the ability to determine the party's general course of action and to decide on a wide range of topics. A clear indication of the new LSP's efforts to maintain and replicate a mass-party organization across the peninsula is provided by the existence of an Organizational and Territorial Federal Officer, who is appointed by the Federal Secretary. 


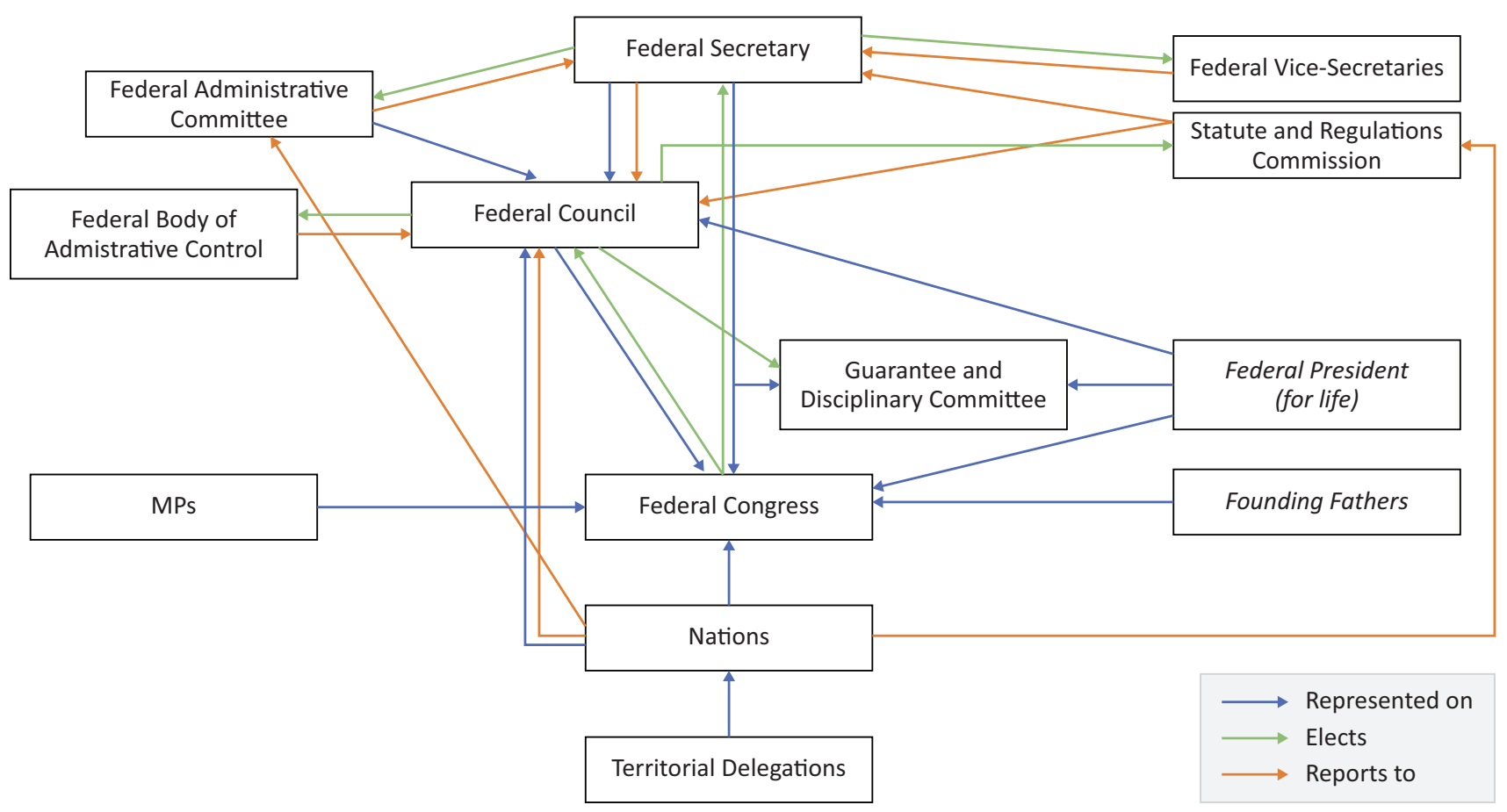

Figure 3. Organizational chart of the LN, "the bad company." Bodies in italics do exist in the LN but do not exist in the new LSP. Source: Own elaboration based on LN (2021).

The LSP is structured into different territorial levels: federal (i.e., state-wide), regional, provincial, and municipal. These are connected by a delegated structure. Each sub-national level of the organization almost perfectly mirrors the bodies of the federal party at smaller scale, thus resembling a matryoshka doll. While the old LN was structured in thirteen regional units called "nations," in the North and Centre of the peninsula, the LSP is constituted by twenty-two regional territorial articulations covering the entire Italian territory, which are formally bestowed with organizational, administrative, patrimonial and financial autonomy. The word "nation," which was previously used to refer to each of the individual regions and was so important in the federalist imaginary of the old LN, is never used in the federal statute of the LSP, suggesting a dramatic ideological and symbolic rupture with the past.

The LSP is further structured into provincial and municipal branches, called "territorial delegations." The provincial branch coordinates the activities of municipal branches, which are based upon a network of activists, and constitute the backbone of the organizational architecture of the party. Northern party representatives highlight that local branches meet on a regular basis (usually at least once a month, and on a weekly basis in some areas) and emphasize their decisive role in achieving territorial rootedness. This network is also essential for the recruitment, screening, socialization, value-infusion, and control of activists.

However, there are important differences between Bossi's LN and the Salvini's LSP in terms of their relative degree of organization. First, various representatives underline that, even in the North, it is no longer possible to ensure the physical existence of local branches in small towns where there are few activists, which consequently need to be aggregated in super-municipal branches (interview 22). Second, while the LN featured a plethora of ancillary organizations, this universe was already gone before the election of Salvini as party leader (interview 4). However, today's LSP still features the most important and energetic of its ancillary organizations of the past: the Lega Giovani (Youth League), the direct heir of the old Movimento dei Giovani Padani (MGP, Young Padanians Movement), which is essential to carry out activities on the ground and serves as a privileged channel for the recruitment of (future) party representatives, at least in the North (interview 37).

In the light of the discussion above, there are good reasons to consider the League as the "most structured political party in Italy" (interview 17), at least as long as the historical strongholds of the $\mathrm{LN}$ are concerned. However, party representatives underline that despite the party's efforts, organizational structuration and territorial rootedness in the South are still in an embryonic phase. Interviewees argue that the LSP has the "willingness to take root" and to "be present on the ground" in Calabria as well as in the broader South, where it "imported a model from the North" (interview 37). However, the LSP's organizational presence is so far "patchy" (interview 27) and only a few areas have a "well-structured group" (interview 40). Interestingly, differently from Northern regions where the local branches are mostly self-financed by local activists, sympathizers and representatives (e.g., interviews 11, 15, 29), the 


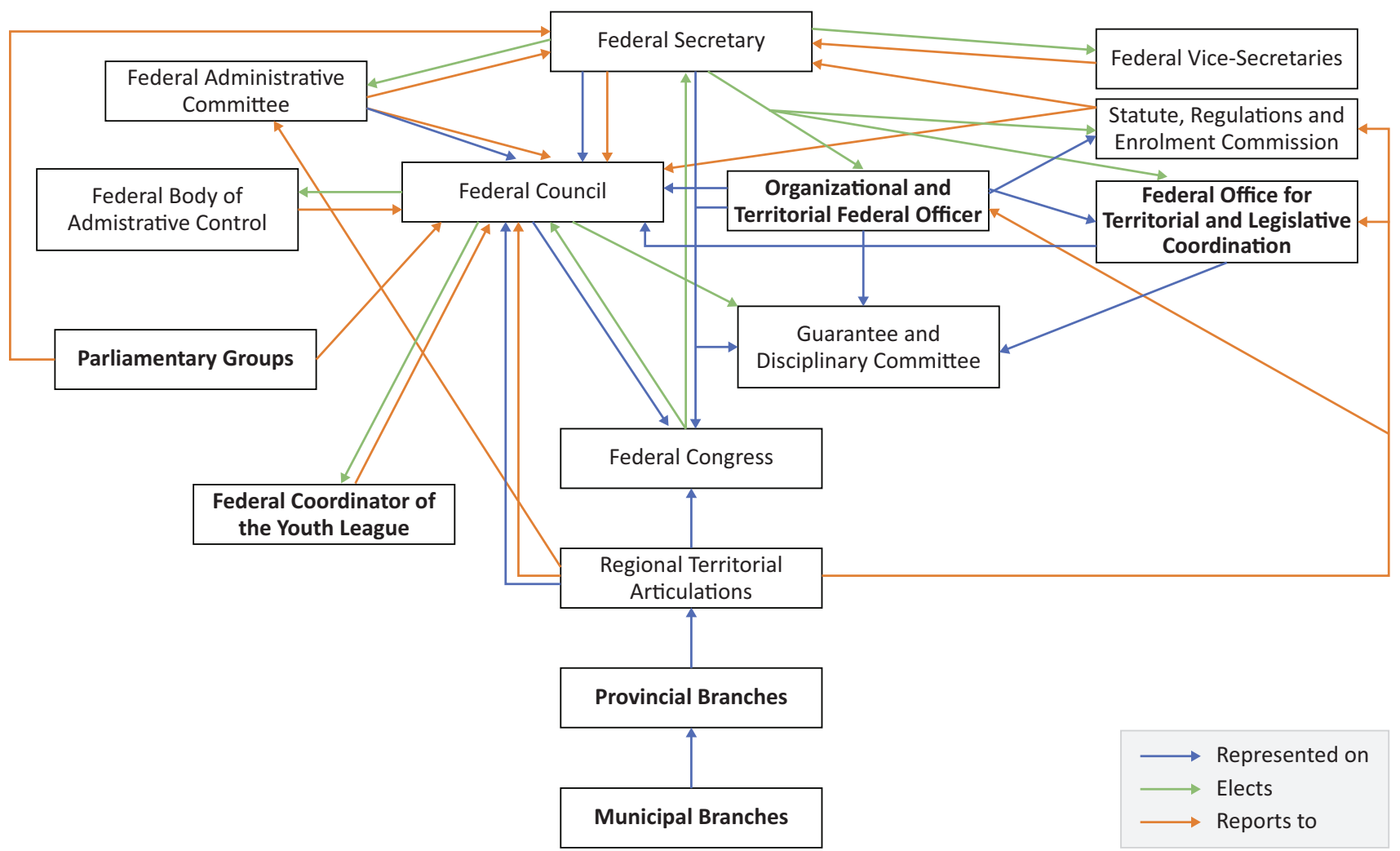

Figure 4. Organizational chart of the LSP, "the good company." Bodies indicated in bold do exist in the LSP but do not exist in the LN. Source: Own elaboration based on LSP (2018).

five physical branches of the LSP in Calabria are directly financed by the national party (interview 40), a feature showing the commitment of the national party to develop an organizational structure in the region.

\subsection{How Does the Party Try to Attract Members and Activists?}

The LN experienced a dramatic collapse in its membership figures following the scandal that led to Bossi's resignation (McDonnell \& Vampa, 2016), and while party officials did not provide me with updated figures on party membership, it is important to recall that the mass-party model is not defined by numbers per se. Rather, inter alia, it is defined by the drive to recruit new members, especially with the goal of developing an activist grassroots base to improve the party's ability to reach out to the wider electorate (see Albertazzi \& van Kessel, 2021).

To understand how the LSP pursues this objective and what incentives it offers to prospective members and activists it is essential to underline that, similarly to the "old" LN, the LSP (2021) distinguishes between soci sostenitori (supporter members) and soci ordinari militanti (activist members). Supporter members are important because they provide some funding by paying EUR 10 every year, while activist members constitute the organizational backbone of the party, as they are entitled to active and passive voting rights and have a duty to participate in its activities on a continuous and regu- lar basis. For the purposes of this analysis, I adopt the re-categorization of Clark and Wilson's (1961) incentives proposed by Albertazzi (2016). According to this scholar, purposive incentives relate to the "importance of party programmatic goals and ideology"; personal incentives evoke a "sense of identity being shaped by activism," which provides a sense of "fulfilment," "satisfaction," or even "a reason to live" to members, while communitarian incentives refer to "the party's ability to create and foster communities of like-minded individuals"; finally, material incentives refer to personal gain or reward acquired by the activist (Albertazzi, 2016, pp. 121-122).

Interviews reveal that potential supporter members are reached "through gazebos, word of mouth, and social media campaigns" (interview 24), and a key role is played by purposive incentives that do not evoke simply the core of the League's message but also its perceived embodiment in Salvini's persona, as suggested in interview 31: "[Salvini] says the things I would say, he says them as I would....To demonstrate my affinity I take the party card." Salvini's alleged capacity to speak on behalf of the ordinary people is perfectly consistent with the selfprofessed populist nature of the party and is strikingly similar to what occurred within Bossi's LN (see Cento Bull \& Gilbert, 2001, p. 21).

Purposive incentives play a crucial role in the recruitment of new supporter members in both the North and the South, while Northern party representatives argue that a key role in becoming an activist member 
is played by "self-motivation" (e.g., interviews 1, 14, $21,30)$. Northern representatives also underline that activist members' recruitment is fostered by purposive incentives related to the desire to actively contribute to the achievement of party goals and by the provision of communitarian incentives. Significantly, communitarian incentives are also essential to maintaining activist members over time, because being a leghista (i.e. a member or sympathizer of the League) often has negative repercussions on private life, social relationships, and even personal finance. Most notably, in the North, these costs are compensated by the development of a "microcosm, where the affections, in some cases even colleagues, friends... the personal world is built within the boundaries of leghismo" (interview 9). This microcosm corresponds to a community of true "believers" (Panebianco, 1988, p. 26), a key feature of mass-parties, and helps to protect the party from careerists and infiltrators.

Finally, some representatives consider the possibility of becoming a candidate in elections a further reason to become an activist member of the League. However, given the demanding nature of activism within the party, the importance of this material incentive appears subordinate and secondary in comparison to purposive and communitarian ones, at least in the North. In the South, instead, given the newness of the party organization, activist members are still few and, most importantly, the LSP is often blamed for choosing candidates with little or no previous experience of activism in the party (interviews $38,39,40$ ).

\subsection{The Role of the Internet and Social Media in Party Organization and Activism}

The LSP has taken advantage of the cost-effectiveness and immediacy of new technologies to perform the typical functions of mass-parties in a modern way, a necessity following the abolition of direct public funding to political parties in Italy. WhatsApp and Facebook groups are now essential to coordinate party activities and to foster activism more generally. Indeed, they are crucial to organize and advertise, in a cost-effective and immediate way, a wide range of political and non-political activities on the ground, as well as to ensure a continuous flow of communication, which results in a sort of internal party broadcasting that favours value-infusion and member encapsulation.

The LSP has its own website and is active on all the major social media platforms (Facebook, Instagram, Twitter, YouTube); virtually all municipal branches of the party have a Facebook page. Salvini himself is very active on social media and has personal profiles on Facebook, Instagram, TikTok, Twitter, and YouTube. Salvini is not only the Italian politician with the largest number of followers on all the social media platforms, but his success is remarkable even in a comparative perspective: In early 2020 he became the first political leader in Europe to reach 4 million followers on Facebook.
However, Salvini's popularity and the unprecedented personalization of the party message and public image under its leader should not lead to the conclusion that today's LSP has abandoned the mass-party model, nor that it has become a property of its leader. Indeed, the LSP is far from being a "personal party" (cf. Kefford \& McDonnell, 2018). Of course, Salvini has the "brand, which today is personified in the persona of the leader" (interview 10), and interviewees commonly underline the vital importance of personalization for the electoral rise of the party (e.g., interview 19). However, personalization does not mean that the expectation of the LSP's lifespan is perceived to be dependent on the political lifespan of its current leader, something that, instead, is typical of personal parties (Kefford \& McDonnell, 2018). In fact, Northern representatives do acknowledge a potential scenario "after Salvini" (interview 20): "We feel leghisti, and we feel to be the party. So, whether the leader of the party is called Bianchi, Neri, Rossi, Verdi, or whatever the name, one is always a leghista" (interview 19). Of course, this applies to the North, while whether the party has a future in the South in a "post-Salvini" era is open to debate.

Having clarified why Salvini's party should not be considered a personal party, it can be underlined that the new LSP is fostering a modern interpretation of the mass-party model through the systematic usage of the TRT formula (TV, rete, territorio, that is, television, network, territory) developed by Salvini's strategist, Luca Morisi. The TRT formula informs party workings at all levels and can be understood as a powerful way of bridging physical and digital activism; this principle is clearly inspired by marketing, in which the blend of the physical and digital worlds is commonly referred to by the term "phygital." The TRT formula implies the continuous interaction and coordination of party activities and messages between traditional media, social media and activism on the ground (interview 18), hence "multiply[ing] the message... hundreds, thousands of times" (interview 17). This formula is taught in cadre schools and regularly adopted by party representatives at all levels, as explained in interviewe 18:

I'm a small cog in a big machine, but tonight I'll be on local TV, I'll put my banner on the social networks....The next day l'll broadcast the video of my interview on TV using a new media..... In the morning I'll be doing a gazebo, so: TV-network-territory in a continuous way.

The TRT formula delivers the image that the League and its key representatives are present "on the ground," differently from the other parties that have long abandoned their societal roots and linkages with the "ordinary man." Thanks to the pervasive adoption of the TRT formula, the LSP has pioneered a modern form of massparty built upon phygital activism, through which it is capable of performing key functions and activities of the 
traditional mass-party in a more efficient and immediate way. Physical and digital activism reinforce each other, producing an amplifying effect that boosts the visibility of the party at the mass-level, delivering the image that the LSP, its representatives, and activists are constantly on the ground.

It is important to underline that the success of the TRT formula requires the presence of local committed activists for reasons related to both logistics (e.g., the concrete organization of a gazebo) and credibility (e.g., leafleting is more effective when made by locals), because "no communication agency nor no amount of money would give you the same result" (interview 18). Also in Calabria, people get closer to the LSP if they see representatives or activists "on the ground and social media, making an effort to solve a problem" (interview 40). However, given the uneven and spotty organizational development of the LSP in Calabria (interview 27), in many areas of the region (and of the South more generally), the TRT formula is still disproportionately focused on the persona of Matteo Salvini, who aims to compensate for the lack of territorial presence. Following the principles of the TRT formula, Salvini regularly travels across the peninsula to take part in various events, and his visibility is amplified through the usage of traditional and social media. While this strategy is functional to gathering votes and public attention, with Salvini being often seen as "the only leader who comes to visit these areas" in the South (interview 32), this is also criticized by some interviewees who complain that it hinders organizational development and political activism:

[Activists] only speak about going to eat pizza, about going to rallies and saying "hooray for Salvini!" "go Salvini!" After which [activism] fades into agony and oblivion. (Interview 38)

Salvini has come to Calabria at times, made a threeminute speech saying the same things, and this was followed by an hour and a half posing for selfies. This is not politics. (Interview 39)

\subsection{Reasons to Grow an Active Base of Members and Activists}

Coherently with its long-standing vocation as a massparty, the League actively seeks to foster an activist grassroots base, which is essential to fulfil disparate internal and external goals, as well as to carry out practical and symbolical functions. Party representatives explain that activists organize a wide range of activities, which include, among others, leafleting, gazebos, local festivals, rallies, protest actions, convivial events, and book presentations. Activism and ideology encapsulate members in what is usually perceived as a "family" or a "team," which make the grassroots activist base a competitive weapon that can be mobilized at any time, at least in Northern regions. The presence of an activist grass- roots base is considered as "what saves you politically" (interview 18), an organizational asset making the LSP "much more resistant when is losing support" and helping it "grow much faster" when conditions are favourable (interview 24). Furthermore, an activist grassroots base is also functional to providing an aura of credibility and authenticity to the LSP's (self-declared) populist nature. Activists are essential to ensure that gazebos and leafleting activities are regularly carried out throughout the year, but also to deliver the idea that the party is always present on the ground to hear citizens' concerns and grievances. This is crucial to differentiate it from the other parties, which, according to many party representatives, show up only during election campaigns.

The long and continuous effort by the League to invest in grassroots activism since the early Bossi years has produced in Northern regions what a representative (interview 9) acutely defined as the "leghista of proximity." As he explains:

In the North is easy to meet someone who is a member of the League, and [this] gives the party a human dimension, in which people can identify, not just because there is Salvini on the television, but also because there is Roberto who is a tobacconist.

Therefore, the leghista of proximity fulfils both practical and symbolical functions: He or she is not only essential to carry out key activities typical of the mass-party for free, but also to provide an aura of authenticity to the LSP. The goal of delivering an image of authenticity is also being pursued in Calabria: "For us it's very important at a communicative level to make people understand that it is us who make the League....Salvini can give indications, but politics is made on the ground" (interview 40).

\section{Centralization and Internal Democracy}

The LSP is a hyper-centralized party following Janda's $(1980$, p. 108) criteria. It is characterized by very little space for internal democracy (even more so than during Bossi's era), and in line with its Leninist imprinting, the organizational imperative of the LSP remains democratic centralism, a feature enabling the party to deliver an image of unity and cohesiveness at the mass-level.

\subsection{Centralization}

The LSP is characterized by the disproportionate concentration of power in three federal bodies, which can be defined as the trident of power: the Federal Secretary, the Federal Council, and the Organizational and Territorial Federal Officer. Whereas the Federal Secretary holds a dominant position, an important concurrent role is played by the other two components of the trident of power, which, directly or indirectly, impact and steer the activities and workings of the LSP at both the federal and sub-national levels (see 
Figure 4). The overall functioning of the party machine is informed by the principle of "democratic centralism" (interview 18), the core organizational imperative of traditional Marxist-Leninist parties. As an influential representative (interview 30) explains:

We discuss, then the secretary makes the synthesis....The Federal Council of the League is compact, united, there are no different souls....There is internal debate, but as soon as the meeting ends we are all compact and united.

Significantly, the LSP's course of action in political and programmatic terms (including party manifestos and electoral alliances, both at the national and sub-national levels), its internal rule-making, its administrative, economic and financial management, as well as the management and enforcement of internal discipline are dominated, directly or indirectly, by the Federal Secretary and the Federal Council, and often register a concurrent role of the Organizational and Territorial Federal Officer. The latter is essential as "it cascades the directives down" to the other levels of the organization (interview 15) and ensures the multi-level coordination of party activities on the ground. Power is also centralized at the federal level in terms of candidate and personnel selection. The Federal Secretary expresses an opinion on the candidatures to elective positions at the various levels, while the Federal Council determines the candidate lists for general and European elections and ratifies the regional branches' proposed candidacies for the positions of regional governor and regional capitals' mayors, as well as their respective candidate lists.

In the historical strongholds of the party, the organizational Leninist mould still de facto survives, aiming at bringing within institutions representatives socialized to party values and hierarchy, trained in party cadre schools, and selected following a strict cursus honorum. However, even though such a cursus honorum is widely valued by representatives (e.g., interviews 3, 10, 11, 24), who underline the importance of "paying your dues," the new party regulation (LSP, 2021, Art. 17), maintains that "the Federal Council can establish, for each single electoral session of any level, the criteria of seniority of membership necessary to propose candidates or to be candidates." This provision seems particularly relevant for the South and suggests a further centralization of power in the hands of the federal party. More generally, candidate lists and alliances at the sub-national level require approval from the hierarchically superior level. It is also worth stressing that the League's communication is also hyper-centralized, through a cascade pattern from the federal level down to the municipal one, a feature that favours a coordinated implementation of the previously mentioned TRT formula.

Broadly speaking, the federal level dominates the sub-national levels through the so-called sistema di controllo e garanzia (system of control and guarantee), which makes sure that the various levels of the party organization are checked, monitored and held accountable to those that are hierarchically superior. This mechanism ensures organizational coordination and coherence. Deviations from the federal party line are regulated by means of commissariamenti, that is, the replacement of a given monocratic or collegial body with commissioners, who are granted full powers in a given territorial area.

The instrument of commissariamenti played a decisive role in the disempowerment of the old LN in favour of the new LSP. In the North, by taking advantage of the impossibility of having sub-national congresses given the formal preclusion of dual membership in the "old" and "new" League, Salvini used the instrument of commissariamenti to replace various elected secretaries and collegial bodies of the "old" LN. This strategy has served a double function: on the one hand, maintaining the consolidated structure that the LN had established in its historical strongholds; on the other, ensuring that key positions within the party were held by individuals loyal to the leadership and to the party's new ideological course.

In the South, the loose approach that initially characterized NcS was supplanted by a top-down and centralized approach to party building dominated by the Northern elite and commissioners from the North. Commissioners were granted full powers in the area of their competence and given the task of exporting the key features and internal mechanisms that characterized the old LN to the South, while attempting to protect the process of party building from infiltrators and careerists. Interestingly, most of the commissioners have been Lombards, in line with the historical dominance of this regional branch in the old LN, and have been given the explicit task of exporting its organizational model and even its "mentality" (interview 40). For instance, Cristian Invernizzi, an MP from the Northern city of Bergamo, was regional commissioner in Calabria between May 2019 and January 2021: He was "Salvini's emanation in Calabria," and his task was "to organize, structure the party, even dictate the political line" (interview 25), as well as to trying "to foster the leghista mentality" in the area (interview 40). Unsurprisingly, this Northern commissioner was often criticized by the Calabrian grassroots for his top-down management of the party (interviews 38, 39).

More generally, the party in the central office seeks, in the South, "to protect the brand, in a way. If you get a criminal elected because you have not checked before... the main damage is suffered by the brand," to the point of being "even paranoid at times" (interview 31), but this results in the LSP being perceived as "detached from the real needs of the territory" (interview 38). The difficult task of also protecting the brand from individuals using the party as a "train" just to pursue a political career (interview 40) is pursued in particular thanks to the action of commissioners who oversee candidature lists and control appointments to internal party positions (interviews 15, 25, 27, 31, 32, 39). 
All in all, the League's organization looks:

A bit military....We make clear that there is a hierarchy and that this hierarchy cannot be questioned in any way [but] we have some difficulties in building the structure in the South, because we try to convey... the concept of hierarchy... but there they all want to be protagonists. (Interview 31)

Finally, it is worth underlining that exporting the organization model of the League into the South is further complicated by the electoral rise of Fratelli d'Italia (Fdl), a populist radical right party (Zulianello, 2020) led by Giorgia Meloni that has a great appeal in the area. Interviewee 38 underlines that " $[\mathrm{Fdl}]$ is the nightmare of the League," and interviewees from the South explain that Meloni's party is attracting not simply former LSP voters, but also former party members (interviews $25,37,39,40$ ).

\subsection{Internal Democracy}

The imperative of democratic centralism leaves very little space for dissenting voices and internal democracy. Supporter members have virtually no rights at all, while activist members are closely scrutinized in terms of loyalty and dedication to the party, subject to disciplinary sanctions ranging from written reprimands to expulsion. All in all, while the duties of activist members are extensive, their prospects to have a say are poor in all the key dimensions of party life and workings.

Northern party representatives underline that local party meetings are important to ensure internal debate and the involvement of activists. However, democratic centralism leaves "the last word" to party secretaries at all territorial levels (interview 12), and this does not commit only activists to the party line, but elected representatives as well. For instance, the LSP's representatives (including MPs) have a duty to regularly report their activities not only to the federal level of the party but also to the sub-national levels of the party organization, such as the municipal branch and the regional branch they belong to. Hence, as it was in Bossi's era, party members can discuss and meet at the various levels of the party organization, often with the participation of elective representatives, but their ability to influence decision-making, the political line and candidatures is close to zero.

While interviewees from the North usually mention the fact that it is possible to easily get in touch with party representatives of the League to ask for information, help or advice, and they interpret this as a form of democracy, just like participating in local party meetings, interviewees from the South tell a different story. They lament the absence of coordination between the party in public office and the party in central office, so that "you don't know where to turn because no one answers you," while internal debate seems poor also during local party meetings because of the extreme centralization of power in the hands of the (federal) party (interview 39).

All in all, the only tool that can be used by members to influence the general course of the League is the election of party leaders at various territorial levels, but this chance has also remained a dead letter in the last few years because of the widespread usage of commissariamenti. Although party congresses at all levels were initially frozen because of the transition from the old LN to the new League, the Covid-19 pandemic has contributed to postpone them sine die, raising profound concerns among many interviewees in both the North and the South.

Finally, it is worth mentioning that an important innovation in terms of internal democracy was the extension of the electorate for federal leadership elections in both 2013 and 2017-from congress delegates to activist members with at least one-year seniority, as a derogation from the formal statutory provisions. However, rather than actually democratizing the party, primary elections resembled plebiscitarian coronations for Salvini, who obtained crushing victories against his rivals. These translated into a "surplus" legitimacy that Salvini exploited to both abandon the regionalist ideological raison d'être of the $\mathrm{LN}$ and to transform it into a politically inactive bad company.

\section{Conclusion}

Today's LSP is characterized by a kind of "territorial dyscrasia." In the North, the LSP inherited the organizational capital of the old $L N$ and exploits it to carry out the traditional functions and activities of the massparty model in a modern way. In the South, the LSP is better understood as a "wannabe" mass-party, as it actively tries to replicate the organizational features and practices it has consolidated in the North. However, exporting, instilling and routinizing the organizational imperatives of loyalty, activism, and dedication will be a very demanding and time-consuming enterprise. Organizational development in the South remains at an embryonic stage, and the LSP's strategy for nationalization has so far produced a "quasi-colonial" structure dominated by, and dependent on, the Northern elite.

This article has crucial implications for our understanding of the mass-party organizational model in the contemporary world. While Bossi's LN was a mass-party in a traditional sense, the case of the LSP suggests that new technologies can be successfully exploited to develop a modern form of mass-party. As previously mentioned, a key feature of mass-parties is the development of an activist grassroots base to improve the party's ability to reach out to the wider electorate (Albertazzi \& van Kessel, 2021).

In this respect, this article has suggested that LSP is characterized by the desire to act and be perceived as a mass-party; however, it has pioneered an innovative interpretation of the latter organizational model. 
Indeed, the LSP can be understood as a modern massparty whose key feature is ceaseless phygital activism, which is a blend of digital and physical activism that is far from being limited to election times. Phygital activism is sought on a continuous basis and aims at boosting the visibility of the party at the mass-level, thanks to a synergy between traditional in-person and face-to-face activism, performed by a grassroots base, and modern online activism, carried out through social media and instant messaging systems.

A modern mass-party grounded on phygital activism aims to deliver the image that the party is constantly on the ground to collect citizens' concerns, and the continuous interaction between physical and digital activism also fosters the development of a political community that encapsulates members through ideology. Most notably, these are key functions performed by mass-parties: The case of the LSP suggests that phygital activism enables the reinterpretation of a traditional organizational model in a modern, more efficient, immediate, and less bureaucratic way, making it an asset capable of meeting the challenges of the twenty-first century.

\section{Acknowledgments}

The support of the Economic and Social Research Council (UK) is gratefully acknowledged (Grant Ref: ES/R011540/1).

\section{Conflict of Interests}

The author declares no conflict of interests.

\section{Supplementary Material}

Supplementary material for this article is available online in the format provided by the author (unedited).

\section{References}

Albertazzi, D. (2016). Going, going... not quite gone yet? "Bossi's Lega" and the survival of the mass party. Contemporary Italian Politics, 8(2), 115-130.

Albertazzi, D., Giovannini, A., \& Seddone, A. (2018). “No regionalism please, we are Leghisti!" The transformation of the Italian Lega Nord under the leadership of Matteo Salvini. Regional \& Federal Studies, 28(5), 645-671.

Albertazzi, D., \& McDonnell, D. 2015). Populists in power. Routledge.

Albertazzi, D., \& van Kessel, S. (2021). Right-wing populist party organisation across Europe: The survival of the mass party? Introduction to the thematic issue. Politics and Governance, 9(4), 224-227.

Albertazzi, D., \& Zulianello, M. (2021). Populist electoral competition in Italy: The impact of sub-national contextual factors. Contemporary Italian Politics, 13(1),
4-30.

Borz, G., \& De Miguel, C. (2019). Organizational and ideological strategies for nationalization: Evidence from European parties. British Journal of Political Science, 49(4), 1499-1526.

Borz, G., \& Janda, K. (2020). Contemporary trends in party organization: Revisiting intra-party democracy. Party Politics, 26(1), 3-8.

Cento Bull, A., \& Gilbert, M. (2001). The Lega Nord and the northern question in Italian politics. Palgrave.

Clark, P. B., \& Wilson, J. Q. (1961). Incentive systems: A theory of organizations. Administrative Science Quarterly, 6, 129-166.

Electoral Archive of the Italian Interior Ministry. (2021). L'Archivio [The archive; Data set]. https:// elezionistorico.interno.gov.it

Heinisch, R., \& Mazzoleni, O. (Eds.). (2016). Understanding populist party organisation. Palgrave.

Janda, K. (1980). Political parties: A cross-national survey. Free Press.

Kefford, G., \& McDonnell, D. (2018). Inside the personal party: Leader-owners, light organizations and limited lifespans. The British Journal of Politics and International Relations, 20(2), 379-394.

Kvale, S. (1996). InterViews: An introduction to qualitative research interviewing. SAGE.

Lega Nord. (2015). Statuto della Lega Nord per I'Indipendenza della Padania [Statute of the Northern League for the independence of Padania]. www. leganord.org/phocadownload/ilmovimento/statuto/ Statuto.pdf

Lega Nord. (2021). Statuto della Lega Nord per I'Indipendenza della Padania [Statute of the Northern League for the independence of Padania]. https://www.leganord.org/phocadownload/ ilmovimento/statuto/LN_Statuto_2021.pdf

Lega per Salvini Premier. (2018). Statuto [Statute]. https://static.legapersalvinipremier.it/files/ Lega_per_Salvini_Premier_Pubbl_Statuto_GU_ n.272_del_22_11_2018.pdf

Lega per Salvini Premier. (2021). Regolamento [Regulation]. https://static.legapersalvinipremier.it/files/ 2021-05-15\%20Regolamento\%20LPSP.pdf

McDonnell, D., \& Vampa, D. (2016). The Italian Lega Nord. In R. Heinisch \& O. Mazzoleni (Eds.), Understanding populist party organisation (pp. 105-129). Palgrave.

Mudde, C. (2007). Populist radical right parties in Europe. Cambridge University Press.

Newth, G. (2019). The roots of the Lega Nord's populist regionalism. Patterns of Prejudice, 53(4), 384-406.

Panebianco, A. (1988). Political parties: Organization and power. Cambridge University Press.

Stockemer, D., Lentz, T., \& Mayer, D. (2018). Individual predictors of the radical right-wing vote in Europe: A meta-analysis of articles in peer-reviewed journals (1995-2016). Government and Opposition, 53(3), 569-593. 
Zulianello, M. (2019). Anti-system parties: From parliamentary breakthrough to government. Routledge.

Zulianello, M. (2020). Varieties of populist parties and party systems in Europe: From state-of-the-art to the application of a novel classification scheme to 66 parties in 33 countries. Government and Opposition, 55(2), 327-347.

\section{About the Author}

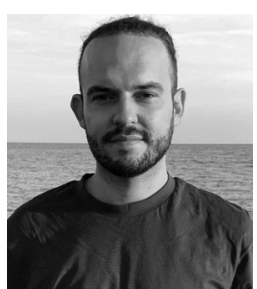

Mattia Zulianello is assistant professor of political science (tenure-track) at the Department of Political and Social Sciences at the University of Trieste, Italy, and previously was research fellow at the Department of Political Science and International Studies of the University of Birmingham, UK. He is the author of Anti-System Parties: From Parliamentary Breakthrough to Government (Routledge, 2019) and his research interests include anti-system parties, populism, party systems, and mixed-method approaches. 